\title{
The Role of Bioenergy in Achieving the Carbon Neutrality Target in Finland by 2035-A Case Study of Student Surveyed at University in Finland
}

\author{
Tapio Ranta, Mika Laihanen, Antti Karhunen \\ Lappeenranta-Lahti University of Technology, LUT, School of Energy Systems, Lappeenranta, Finland \\ Email: tapio.ranta@lut.fi
}

How to cite this paper: Ranta, T., Laihanen, M. and Karhunen, A. (2021) The Role of Bioenergy in Achieving the Carbon Neutrality Target in Finland by 2035-A Case Study of Student Surveyed at University in Finland. Journal of Sustainable Bioenergy Systems, 11, 61-81.

https://doi.org/10.4236/jsbs.2021.112005

Received: May 8, 2021

Accepted: June 15, 2021

Published: June 18, 2021

Copyright $\odot 2021$ by author(s) and Scientific Research Publishing Inc. This work is licensed under the Creative Commons Attribution International License (CC BY 4.0).

http://creativecommons.org/licenses/by/4.0/

(c) (i) Open Access

\begin{abstract}
The largest share of renewable energy in Finland comes from bioenergy. In 2019 , bioenergy accounted for 82\% (416 PJ, $116 \mathrm{TWh}$ ) of renewable energy in Finland. This study assesses the potential for increasing bioenergy in energy production by 2035 and what role it will play in achieving the carbon neutrality target in Finland. The role of different energy sources in the energy system was examined using existing scenarios developed for The National Long-Term Strategy. Two alternative low-emission scenarios have been developed to last until 2050 to meet the 2035 carbon neutrality target. In 2035, the amount of bioenergy has risen to 520 - $550 \mathrm{PJ}$ (144 - $153 \mathrm{TWh}$ ), which is about $70 \%$ of renewable energy consumption. This means, that the bioenergy resource has been fully deployed and the relative share of bioenergy in renewables has decreased slightly. The study also included a survey to university students to map out how likely a carbon neutrality target is to be considered by 2035 . University students were unsure of achieving the carbon neutrality target by 2035 . The schedule was considered challenging especially in the transport sector. Bioenergy was also seen as still playing an important role, especially in heat production. Achieving significant emission reductions will require significant electrification in all energy use sectors, as fossil fuels cannot be sustainably replaced by bioenergy on a sufficiently large scale.
\end{abstract}

\section{Keywords}

Bioenergy, Renewable Energies, $\mathrm{CO}_{2}$ Reduction, Strategies, Policies, Education

\section{Introduction}

In Finland, the share of renewable energy sources in 2019 was $37 \%$ of total 
energy consumption (Figure 1) [1]. The largest share of renewable energy in Finland comes from bioenergy. In 2019, bioenergy accounted for $82 \%$ of renewable energy in Finland. The most significant source of bioenergy is wood-based energy, total $377,726 \mathrm{TJ}$ being $74 \%$ of renewable energy in 2019. Bioenergy also has a significant role to play in the EU, as it currently accounts for almost $60 \%$ (56\% in 2018) of renewable energy use, and bioenergy is expected to continue to grow in the coming decades [2]. The role of renewable energy is high in the Nordic countries in all end-use sectors [3]. Although the use of renewable energy sources has increased in Finland, a considerable amount of fossil fuels, such as oil $(308,493 \mathrm{TJ})$, coal $(90,025 \mathrm{TJ})$ and peat $(56,308 \mathrm{TJ})$, are still used in energy production. In 2019, fossil fuels and peat accounted for $38 \%$ of total energy consumption.

Finland has set a goal to be carbon neutral by 2035 [4]. The term carbon neutrality means that the emissions of Finland's regional greenhouse gases and the sequestration caused by sinks are in balance. Critical factors for achieving the carbon neutrality goal are more efficient use of energy in all sectors of society, a significant increase in renewable energy and the electrification of the energy system. Consumption habits also play a key role. Accelerated emission reductions in all sectors are needed and carbon sinks need to be strengthened. This means that Finland must reduce emissions by about 60 percent by 2035 compared to the current level of $53 \mathrm{Mt} \mathrm{CO}_{2}$ eq in 2019 [5]. In this case, the remaining emissions are about $21 \mathrm{Mt} \mathrm{CO}_{2} \mathrm{eq}$, and the net sink of the land use sector must be at least equal to this amount of emissions. In 2019, Finland's sink covered 33\% of emissions, while the EU average was about 7\% (2018). Similarly, the EU aims to be carbon neutral by 2050 .

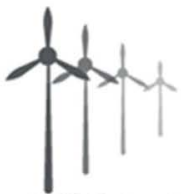

In 2019 the share of renewable energy was $37 \%$

of total energy consumption

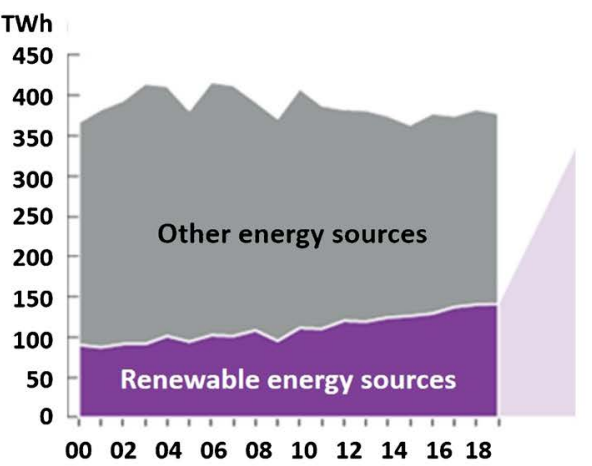

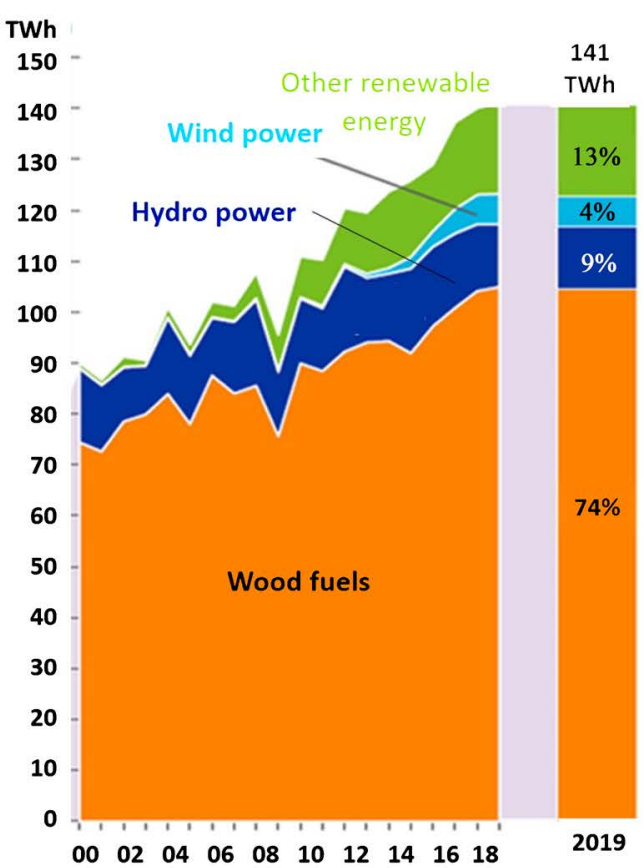

Figure 1. Total renewable consumption by energy source [1]. (Statistics Finland, LUKE). 
The energy use of coal will end by 2029 at the latest with the decisions already made in Finland. According to current forecasts, the main energy use of peat will end during the 2030s as the taxation of peat and the price of emission allowances increase. Similarly, the use of fossil oil for heating will be phased out by the early 2030s. Total energy consumption, i.e., the supply of primary energy and its distribution among different energy sources, is a key factor in terms of greenhouse gas emissions, as fuel-based emissions currently account for about $75 \%$ of total greenhouse gas emissions (excluding the LULUCF sector) [5]. Guidelines on the allocation of emission reductions to different sectors and the necessary measures and actions in the land-use sector have been taken in the context of the preparation of the Climate and Energy Strategy (IE Strategy), the Medium-Term Climate Policy Plan (Kaisu) and the Land Use Climate Program.

Bioenergy is expected to play a significant role as a substitute for fossil fuels, especially in separate heat production and combined heat and power production. In addition, increasing bioenergy is seen as having employment and regional policy benefits. On the other hand, the challenges of increasing the use of bioenergy relate to its competitiveness and availability, which is linked to the sustainability of bioenergy supply, as well as to the technical challenges of replacing fossil fuels. Bioenergy can only be co-combusted to a limited extent in coal boilers, while in existing fluidised bed boilers using peat, it is easier to increase the proportion of wood fuels. However, there are some 50 peat-using plants in Finland where full peat replacement is not possible without investments. Also, replacing oil with bioenergy often requires investing in a totally new boiler which is suitable for biofuels. Security of supply may also be reduced if increasing the use of wood fuels requires an increase in wood imports. Also, the storability of wood biomass is weaker than coal and peat.

Increasing renewable energy has proven to be the most significant way to reduce emissions. Many studies have explored the potential of a 100\% RES system on a sector, city, or country basis [6], especially in the EU, e.g., for Finland by 2050 [7]. These studies have focused in particular on the growth potential of solar photovoltaics (PV) and wind energy technologies. This is part of the move towards a carbon-free energy system. Achieving a carbon-free energy system has been studied, especially for island states such as Japan [8], Iceland [9], Mauritius [10], the Canary Islands [11] and Greek islands [12], but also for larger countries on the continent, such as Brazil [13], which themselves have sufficient potential to make a significant contribution to renewable energy. Typically, the goal is set quite far into the future, such as 2050 , to be able to make the necessary investments in the energy system. It will be easier and faster to achieve the carbon-neutral goal in a specific city [14] or sector [15]. Especially the electricity generation has the highest potential to contribute to the carbon neutrality target in the near future.

Fossil-based district heating is typically the largest source of emissions in large cities [16]. The importance of electricity will also increase in district heating, 
while the role of non-combustion technologies, such as heat pumps, will increase [17]. In this case, fluctuations in the price of electricity can also be utilised through thermal energy storages [18] and better energy system integration [19]. In Finland, the large role of nuclear power and wind power has increased as alternatives to a carbon-neutral energy system, and alternatives without nuclear power have also been presented [20]. The electrification of society is then seen as the most significant way to reduce emissions even without nuclear power as a Japanese case study shows [8].

This study assesses the potential for increasing bioenergy in energy production by 2035 and the role it will play in achieving the carbon neutrality target in Finland based on the strategies by the government and scenarios modelled with TIMES-VTT [21]. The possibilities of additional use of bioenergy are examined both in terms of supply and use possibilities in different end-use sectors, including the possibilities for Bioenergy Carbon Capture and Storage (BECCS). The study reviews the various end uses of fossil energy and assesses the potential for additional use of bioenergy in addition to other renewable energy sources, such as geothermal, waste heat recovery and heat pumps as sources of heat and wind and solar as sources of electricity. The impact of fuel changes on the entire energy system is assessed, such as the replacement of combined heat and power production by separate heat and electricity production and the replacement of fuel combustion by electrification. The study also includes a survey of university students to map out how likely a carbon neutrality target is to be considered by 2035 and what the most important methods to achieve this goal.

\section{Material and Methods}

\subsection{Current Production of Electricity and Heat by Energy Sources}

In 2019, the production of electricity in Finland amounted to $66.0 \mathrm{TWh}$, of which renewable energy sources accounted for $31 \mathrm{TWh}$ (47\%) (Figure 2). Due to nuclear power, the share of fossil-free electricity was $82 \%$. Wood fuels accounted for almost $40 \%$ of renewable electricity, of which 6.8 TWh were produced with black liquor and 5.1 TWh with other wood-based fuels (Figure 3). Domestic electricity production has been declining as domestic production has been replaced by imports, which were around 20 TWh in 2019. The total electricity consumption was $86.1 \mathrm{TWh}$, of which the share of domestic production was $77 \%$. Hydropower causes annual changes in the amount of renewable electricity production according to the water situation. The share of wind power in renewable electricity has clearly increased in recent years; it reached 19\% in 2019 (Figure 3).

In 2019, the production of district heat amounted to 38.1 TWh and industrial heat totalled 55.4 TWh in Finland (Figure 4 \& Figure 5). One of the biggest users of industrial heat is the forest industry, which uses its own fuels, like black liquor and other wood fuels. Fifty-three per cent of heat produced for the needs of industry comes from black liquor. The amount of district heating production 
has leveled off. Most of district heat was produced with wood fuels (35\%), coal $(18 \%)$ and peat (15\%). More district heat was produced with renewable fuels than with fossil fuels for the first time in 2019. Fuel-based production accounted

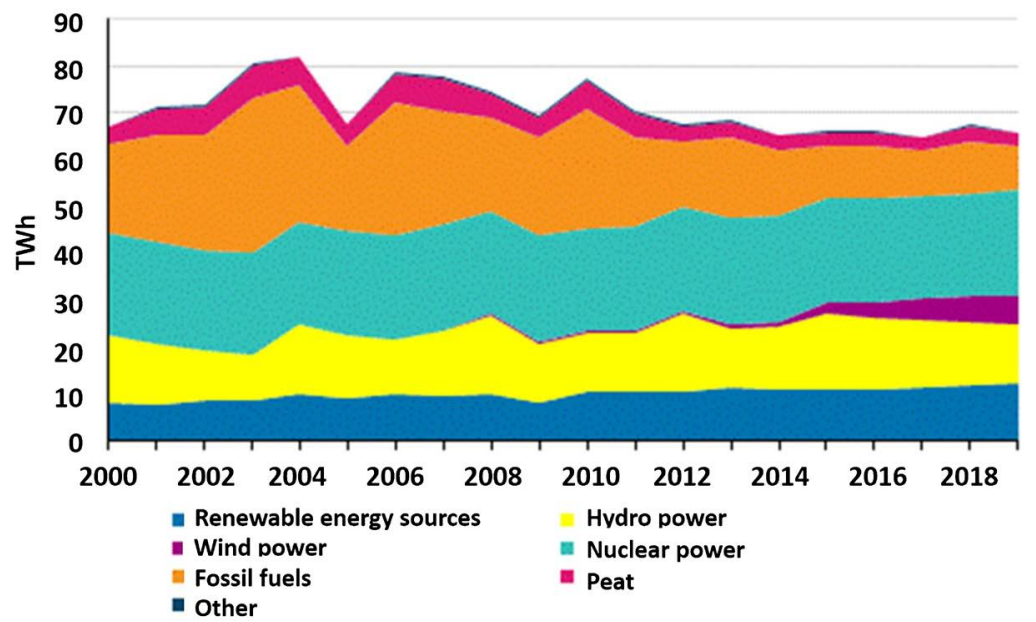

Figure 2. Electricity generation by energy source 2000-2019 (Statistics Finland).

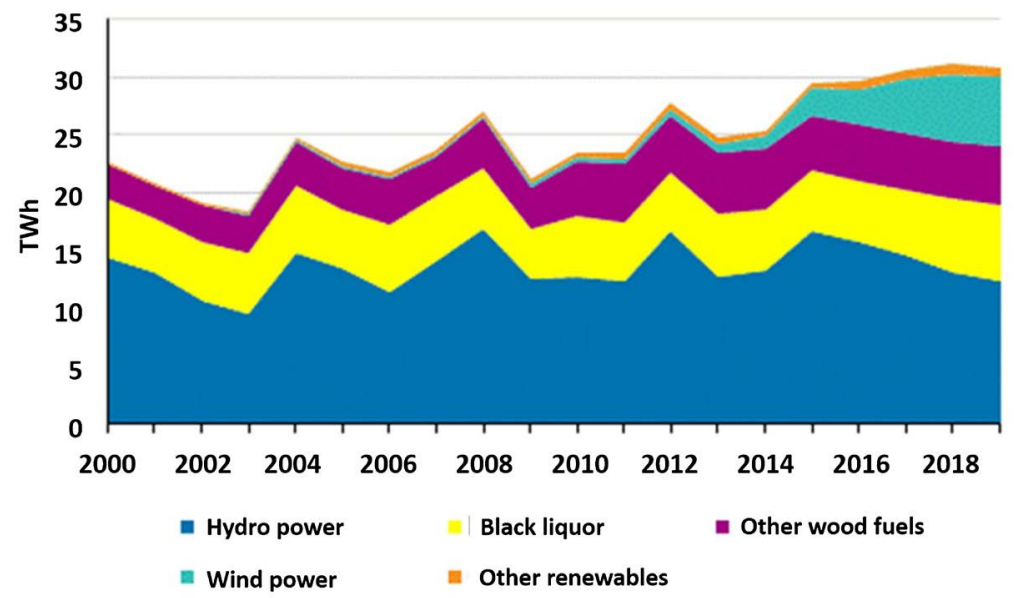

Figure 3. Electricity generation with renewables 2000-2019 (Statistics Finland).

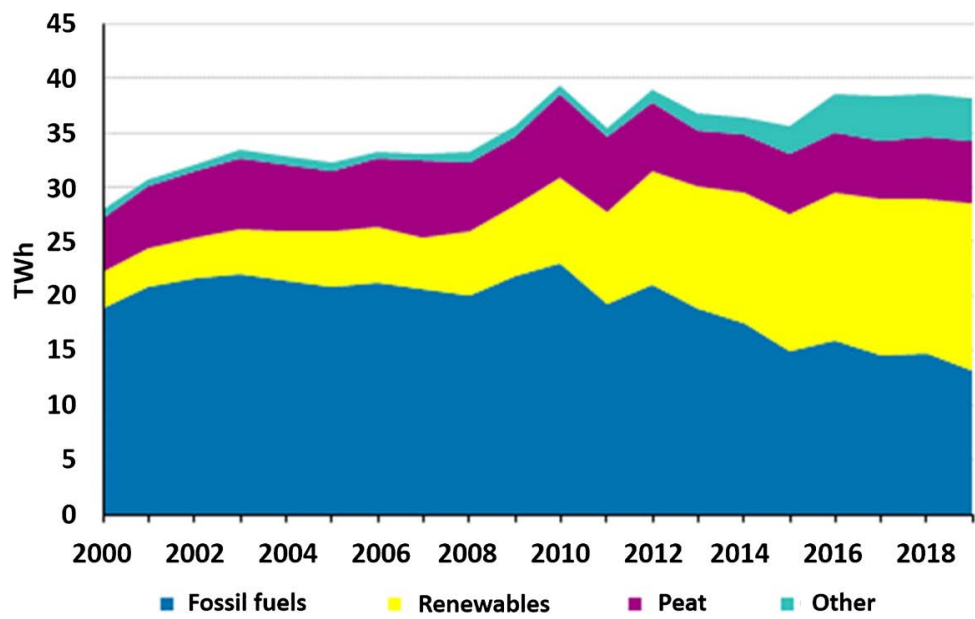

Figure 4. District heat production by fuels 2000-2019 (Statistics Finland). 


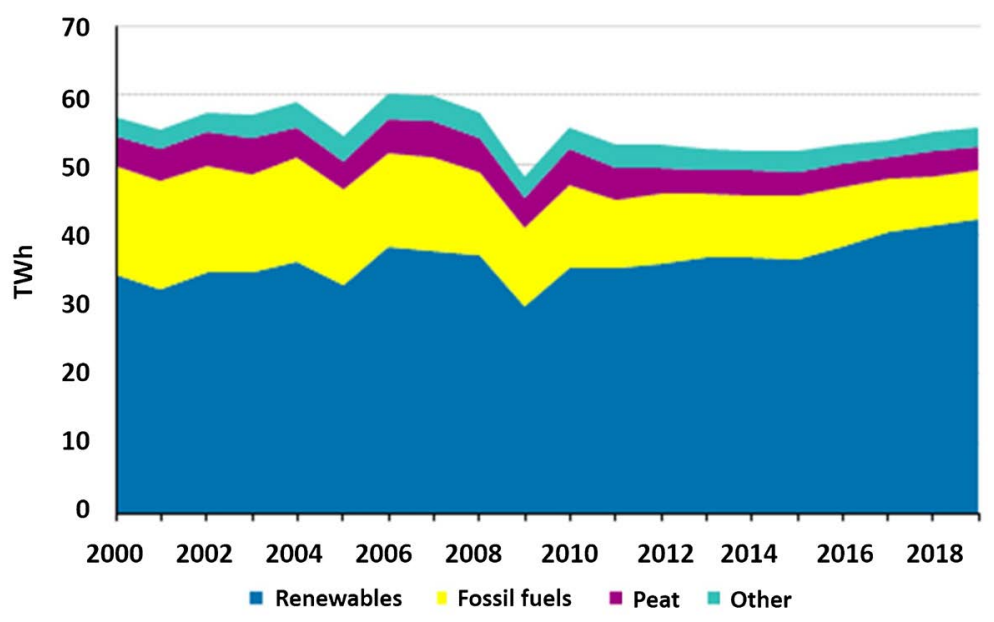

Figure 5. Industrial heat production by fuels 2000-2019 (Statistics Finland).

for $90 \%$ of renewable heat and the rest was produced by heat pumps and waste heat recovery. The share of non-combustion technologies is expected to increase significantly in the future. In its membership survey, the energy industry estimates that its share will rise to $30 \%$ by 2030 . Heat pumps, other heat generated by electricity, geothermal energy and waste heat recovery are classified as non-combustible energy.

The use of bioenergy in electricity generation is made possible by CHP production. The use of bioenergy focuses on the production of district heating, of which $72 \%$ is made through CHP production (Table 1). The use of biomass in this way is efficient when the efficiency of CHP production is almost $90 \%$. Fuel use and related emissions are lower compared to condensing production. In practice, there is no condensate-based electricity production with wood fuels in Finland.

In total, fossil fuels used in electricity and heat production reached 185,707 TJ (51.7 TWh), which was $36 \%$ of total consumption of fuels. Peat accounted for the largest share of fossil fuels (Table 2). The annual change (2018/2019) was $-12.2 \%$, with the largest decrease having been in coal consumption. At the same time, consumption of all fuels, including renewables, decreased by $4.1 \%$. The decrease in fuel consumption was due to a decrease in electricity $(-2.2)$ and heat $(-0.2 \%)$ production.

\subsection{Alternative Scenarios for the Carbon Neutrality Target}

The National Long-Term Strategy (LTS) presents three scenarios [22]. The scenarios have been developed to account for circumstances through 2050 to meet the 2035 carbon neutrality target. They make assumptions about how Finland's community structure, industry, energy production and the structure of the entire economy will change by 2050 . Low-emission paths also contain assumptions, e.g., changes in housing, mobility, services and consumption patterns. The baseline WEM-scenario (With Existing Measures) is a reference scenario based on the current national energy and climate strategy and the medium-term climate 
Table 1. Electricity and heat production by production mode in 2019 (Statistics Finland).

\begin{tabular}{|c|c|c|c|c|}
\hline & $\begin{array}{l}\text { Electricity, } \\
\text { GWh }\end{array}$ & $\begin{array}{l}\text { District heat, } \\
\text { GWh }\end{array}$ & $\begin{array}{l}\text { Industrial heat, } \\
\text { GWh }\end{array}$ & $\begin{array}{l}\text { Fuels used, } \\
\text { TJ }\end{array}$ \\
\hline \multicolumn{5}{|l|}{ Separate production of electricity } \\
\hline Hydro power & 12,239 & .. & .. & .. \\
\hline Wind power & 6025 & .. & .. & .. \\
\hline Solar power & 147 & .. & .. & .. \\
\hline Nuclear power & 22,915 & .. & .. & .. \\
\hline Condensing power & 3142 & .. & .. & 34,842 \\
\hline Total & 44,467 & .. & .. & 34,842 \\
\hline $\begin{array}{l}\text { Combined heat and power produc- } \\
\text { tion }\end{array}$ & 21,576 & 24,022 & 43,397 & 392,446 \\
\hline Separate heat production & .. & 14,120 & 12,007 & 93,489 \\
\hline Total production & 66,043 & 38,142 & 55,404 & 520,777 \\
\hline Net imports of electricity & 20,042 & .. & .. & .. \\
\hline Total & 86,085 & 38,142 & 55,404 & 520,777 \\
\hline
\end{tabular}

Table 2. Fossil fuel consumption in electricity and heat production in 2019, change (2018/2019).

\begin{tabular}{cccc}
\hline Fuel & TJ & Share, \% & Change, \% \\
\hline Oil & 16,011 & $9 \%$ & 9.9 \\
Coal & 51,472 & $28 \%$ & -22.2 \\
Natural gas & 47,345 & $25 \%$ & -11 \\
Other fossil & 16,853 & $9 \%$ & -8.8 \\
Peat & 54,027 & $29 \%$ & -8.8 \\
Total & $\mathbf{1 8 5 , 7 0 8}$ & & -12.2 \\
\hline
\end{tabular}

plan [23] [24]. Two alternative low-emission scenarios have been developed. The Continuous Growth and Savings scenarios describe alternative paths to achieve the low-emission target set by Finland and the EU by 2050. In the Continuous Growth scenario, low-emission targets are achieved through the accelerated introduction of new technology, including strong electrification, digitalisation and industrial renewal. In the savings scenario, the circular economy, the sharing economy and a significant increase in energy efficiency are key elements in achieving the low-emission target. Also, Carbon Capture and Storage technology (CCS) is in use, unlike in the Continuous Growth scenario. In the Savings scenario, the use of CCS technology for bioenergy in turn leads to negative emissions from fuel combustion. Agriculture and forestry act as promoters of the circular economy, as do the replacement of mineral oil-based products with new bioproducts. In the Continuous Growth scenario, the greenhouse gas emission reduction target compared to 1990 emissions is $87.5 \%$ and in the Savings scenario 
$90 \%$, respectively. In addition, both low-emission scenarios meet the 2035 carbon neutrality target, which is in line with the government programme [25].

A number of energy and climate policy targets have been set for 2030 for the low-emission scenarios, which include:

- The target for reducing greenhouse gas emissions in the effort-sharing sector is $39 \%$ compared to the 2005 emission level. The target will have to be raised later due to the EU's tightening emissions target of $55 \%$ by 2030 .

- Abandonment of coal energy use by 2029 at the latest.

- At least halve the use of peat by 2030 .

- The share of biofuels in the energy consumption of road transport in 2020 will be $13.5 \%$ (without double counting) of the energy content and $30 \%$ by 2030 (increasing linearly). Bioliquid blending obligation (10\%) for light fuel oil for separate heating of buildings and diesel oil for work machines, which will increase linearly from 2020-2030.

- The number of electric cars will be at least 250,000 (all-electric cars, hydrogen cars, rechargeable hybrids) and the number of gas-powered cars at least 50,000 in 2030. Later, the government has set a higher target of 700,000 electric cars by 2030 to halve traffic emissions.

- A minimum share of $38 \%$ renewable energy in final energy consumption in 2020 and a minimum target of 50\% renewable energy by 2030.

- Reach the self-sufficiency target for energy supply (55\%) by 2030 and halve the energy use of imported oil.

The key tool used in modeling and analysing scenarios is the extensive system model developed by VTT: TIMES-VTT, which covers the whole energy production and consumption system as well as greenhouse gas emissions [21]. The solution of the energy system model is based on maximising the surplus of producers and consumers, and the resulting energy supply and end-use system thus satisfies the demand for useful energy as cost-effectively as possible, taking into account, inter alia, taxes, subsidies and return on investment requirements.

\subsection{Biomass Potentials}

Biomass potentials were determined using the Biomass Atlas service maintained by Natural Resources Institute Finland (LUKE) [26]. The Biomass Atlas service can be used to retrieve potential information on forest chips, arable crop by-products, manure, and biodegradable waste and sludge from industry and communities. The most significant potential is related to forest chips. The harvesting potential of forest chips describes the technical and economic possibility of supply raw materials for forest chips. As potential raw materials were evaluated: 1) energy wood from first thinning; and 2) felling residues to be harvested from regeneration felling, i.e., crown mass and stumps. Techno-economic potential refers to the part of the first thinning tree, crown mass and stumps that can be harvested after reductions due to various constraints. Such restrictions include, e.g., the minimum accumulation of energy wood per hectare at the har- 
vesting site, the place of growth and the recovery rate. The technical potential does not describe the availability of forest chips, which depends on, e.g., the forest owner's willingness to sell and the competitive situation. The potentials describe the greatest potential for sustainable timber production. The calculation according to the maximum sustainable harvest of industrial (pulpwood and timber) and energy wood determines the upper limit of felling when the sustainability of timber production in forestry is considered to be desirable. According to the calculation, the maximum sustainable volume of industrial wood accumulation was 80.7 million cubic metres per year.

The spatial data set of arable by-products describes the maximum remediable by-product potential of arable crops based on current cultivation. The by-products are calculated using the yield level, cultivated area, dry matter content and yield index of each plant. The yield index describes the part of the plant that is utilised as the main crop. The rest of the plant is a side stream. In practice, the maximum side stream flow may not all be available, as there are technical and economic constraints on harvesting and part of the side stream must be left in the field to maintain the growing condition.

\subsection{Student Population and Implementation of the Survey}

The survey was conducted for university master's degree students who attended an Energy Economics course at LUT University in 2020 and 2021. One of the themes of the course was the energy systems of the future, so the means of achieving the goal of carbon neutrality were well suited as a topic for students to consider. The background variables of the students were known, and they were gender, nationality, study mode (full-time student, distance learner). Distance learner students were employed, graduated (bachelor's degree), and typically older than full-time students. The education field and progress of studies were also known among full-time students. A total of 120 students responded to the survey in 2020 and 126 in 2021, the majority of whom were Finns and men. The proportion of distance learner students was higher (Figure 6). The significance of background variables on responses was measured with a Chi-square test by

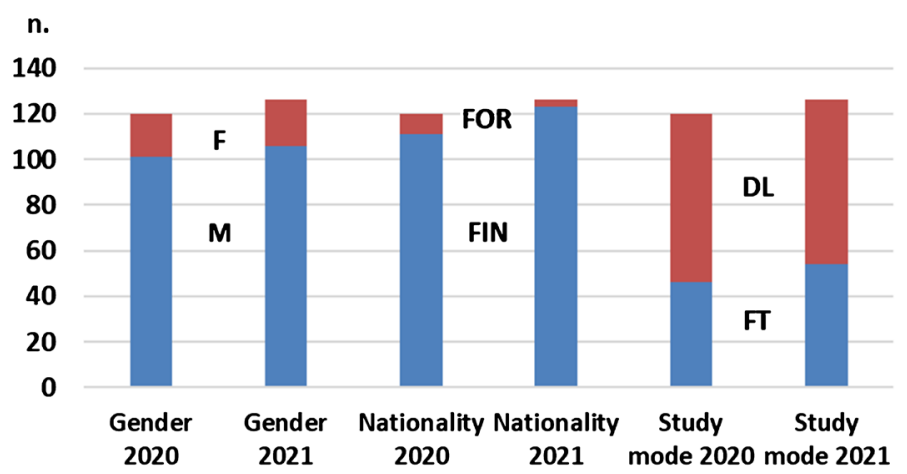

Figure 6. Background variables for students in 2020 and 2021. Gender: Male (M), Female (F); Nationality: Finnish (FIN), Foreigners (FOR); Student: Full-time student (FT), Distance Learner student (DT). 
cross-tabulating the responses.

The survey was conducted on an e-learning platform, Moodle (Modular Object-Oriented Dynamic Learning Environment), during the course. In a digital learning environment, each student was able to answer the question option on their own time and justify their answer. The answers were not given anomalously and were not graded and there was no length limit to the justification of the answers. The choice question offered five options, on the Likert scale "totally agree, somewhat agree, somewhat disagree, disagree, no opinion".

The questions were:

- "Do you believe that Finland will achieve carbon neutrality by 2035?" "The European Union is aiming for carbon neutrality by 2050, but the Finnish government's ambition is to be carbon neutral by 2035. Please, choose the option that you think is most appropriate."

- Can you justify the previous answer?

- What are the main sources of energy (electricity/heat) and the means by which the energy sectors can achieve this objective by 2035 and later by 2050 ?

Students were encouraged to think critically because there are a lot of open questions related to achieving the goal and the means to achieve it. Students understand what carbon neutrality means. Students can be considered a fairly conscious target group for the survey, as they have studied the energy field and are interested in the topic. The result cannot be generalised to a wider target group because the background of the respondents in terms of baseline data was more homogeneous in this case. Respondents are educated for future expert roles and decision-makers in the energy sector, making them an interesting target group.

\section{Results}

\subsection{Renewables and Bioenergy Production in the Future}

The share of renewable energy will increase to $55 \%$ by 2030 and around $70 \%$ by 2035 in low-emission scenarios (Figure 7). Of the renewable energy sources, the use of bioenergy is growing the most in terms of volume. The increase in wind power production will continue to be strong in low-emission scenarios until 2035, after which solar energy will rise alongside it as an energy source that will further increase the share of renewable energy. In addition to these, the heating and cooling energy produced by heat pumps from the environment account for a significant portion of the increase in renewable energy.

Of the renewable energy sources, the use of wood-based bioenergy is assumed to still be the highest, and the increase in use is most pronounced for forest chips and black liquors in the forest industry. In addition, bioenergy will be produced more extensively from agricultural by-products, largely as biogas, but especially from energy crops in the Savings scenario. By 2030, the combined energy consumption of wood fuels (forest industry black liquors and solid wood fuels) will increase significantly, especially in the Savings scenarios, due in part to forest industry production volumes, which increase by-products (e.g., black liquor, 
bark, sawdust) and forest chips. While the total energy consumption of wood fuels in 2019 was approximately $378 \mathrm{PJ}$ (105 TWh), it will increase to 430 - $450 \mathrm{PJ}$ (120 - 126 TWh) by 2030 in different scenarios (Figure 8). After 2030, despite the differences between the scenario stories, the use of wood fuels will remain at approximately the same level and will be 440 - 450 PJ in 2050 (123 - $126 \mathrm{TWh}$ ). In addition to wood-based energy, bioenergy includes agro-biomass, imported biofuels and bio-based waste. They account for less than a fifth of total bioenergy.

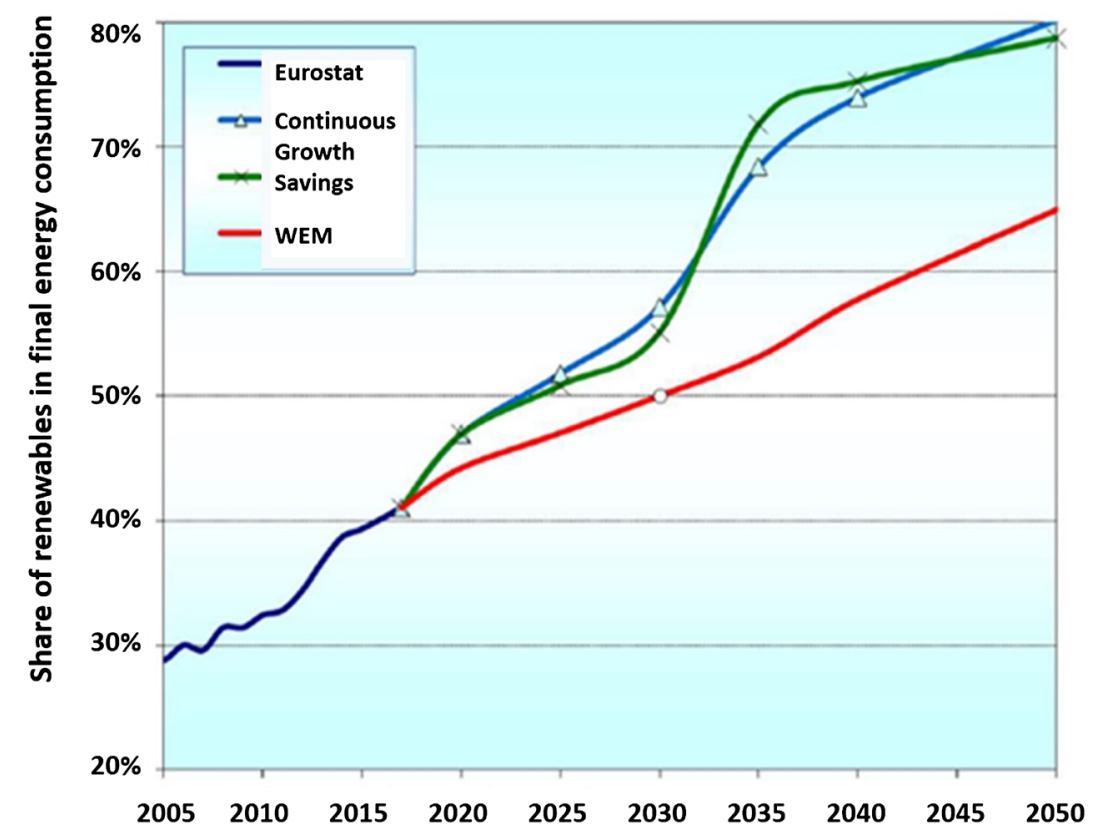

Figure 7. Modelled shares of renewable energy in final energy consumption by scenario [22].

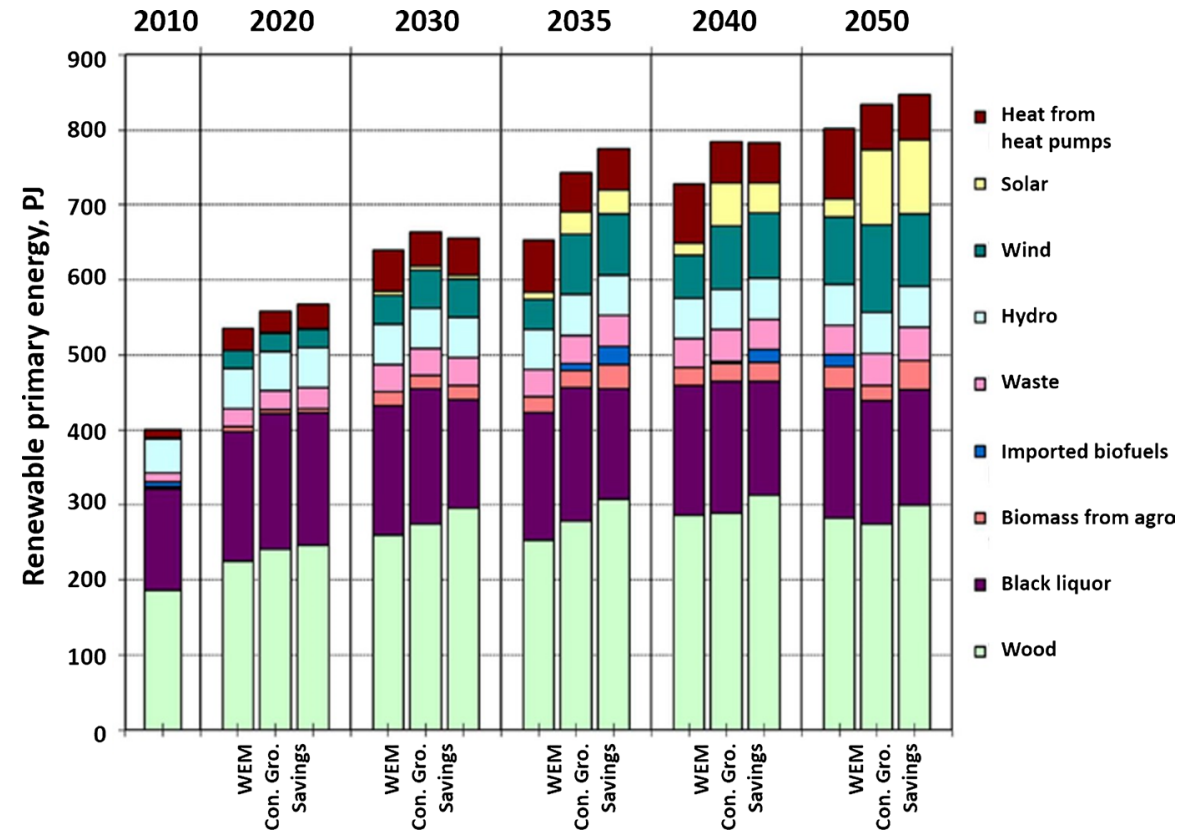

Figure 8. Modelled consumption of renewable primary energy by scenario [22]. 
In the Savings scenario, the use of wood fuels is limited by the growing pulp production of the forest industry, which results in the use of industrial wood limiting the availability of energy wood and raising its price. On the other hand, the demand for advanced biofuels is putting upward pressure on the energy use of wood. The energy use of black liquor is reduced in the Savings scenario by utilising lignin and hemicellulose instead of energy for new bioeconomy products. The use of agricultural by-products will also become visible in the results of the low-emission scenarios, both in biogas production and as energy use for straw. In all scenarios, the energy use of municipal waste will remain at the current level until 2030, at around 20 PJ (approx. 6 TWh), and will then start to decline slightly as a result of more efficient recycling.

Bioenergy use is projected to increase from the current $416 \mathrm{PJ}$ (116 TWh) in 2019 to 520 - $550 \mathrm{PJ}$ (144 - $153 \mathrm{TWh}$ ) by 2035, which is about $70 \%$ of renewable energy consumption. Wood-based energy accounts for more than half of this increase (62 - $72 \mathrm{PJ}, 17-20 \mathrm{TWh}$ ). The rest is formed by agro-biomasses, imported biofuels and bio-based waste with an increase of $41-62$ PJ (12 - 17 TWh).

According to the Biomass Atlas, the techno-economic harvesting potential of forest chips from 2025 - 2034 is 243 PJ. If the potential is limited to felling residues of spruce and small diameter energy wood, it is $98 \mathrm{PJ}$. These describe the biomass fractions that are harvested the most. There are uncertainties associated with sustainability in harvesting stumps and forest owners are unwilling to collect them for energy use [27]. Previous studies suggest similar techno-economic potential without stumps, ranging from 76 to $101 \mathrm{PJ}$ [2]. The lower value describes the potential based on the current level of felling and the upper the maximum sustainable felling volume. MELA calculations also estimate potential in the future, such as by 2035, when the amount is expected to reach $125 \mathrm{PJ}$ [28]. Compared to the current use of 59 PJ, the supply can be approximately doubled, which could almost entirely cover the estimated growth for wood-based bioenergy.

According to the Biomass Atlas, the maximum annual straw potential is 2.5 million dry tons, of which techno-economic harvesting potential is estimated at 1 million dry tons. Animal bedding demand is some 0.4 million tons, leaving 0.6 million tons for energy use, i.e., 10.8 PJ [29]. The current energy use of straw is negligible. The target set for the use of biogas is $4 \mathrm{TWh}$ compared to the current rather moderate use of $0.8 \mathrm{TWh}$. Both agro-biomass and waste are used as raw material for biogas. Bio-based waste also has a clear growth prospect, some of which is used for the production of transport biofuels.

The growth of renewable primary energy is $240-270 \mathrm{PJ}(67-75 \mathrm{TWh})$ from the current by 2035. Bioenergy accounts for $43-50 \%$ of growth, depending on the low-emission scenario. In the Savings Scenario, the share of bioenergy is higher. Wind power production will increase from the current 6 TWh to more than 20 TWh and solar power more than $5 \mathrm{TWh}$. Of the fossil fuels, the current use of $105 \mathrm{PJ}$ (27 TWh) of coal and peat has been completely replaced by bioenergy, 
other renewables, and electricity (cf. Table 2). The use of gas and oil has also decreased significantly.

\subsection{Electricity}

Low-emission scenarios cause quite significant changes in the structure of electricity consumption. Electrification is a key change in all sectors, but its consumption-increasing effect will be largely offset by more efficient energy use. Electricity consumption in low-emission scenarios is around 105 TWh by 2035 (vs. 86 TWh in 2019; Figure 9). The growth of nuclear energy will enable the export of electricity in the 2030s. With fossil fuels, electricity production will come to an end by 2035 . Bioenergy produces about $15-17$ TWh of electricity in combined heat and power production. Wind power production is expected to triple by 2035, exceeding 20 TWh (vs. 6 TWh in 2019). The amount of bioenergy in electricity will not change significantly, but its relative share will decrease as wind and solar power increase by 2035 .

\subsection{District Heating}

Due to both improved energy efficiency and limited carbon-neutral district heating production, district heating consumption will be reduced to less than half of current levels in low-carbon scenarios, reducing the potential for combined heat and power generation in communities. According to the results, the combined heat and power production (CHP) of the municipalities will decrease to 7 - 8 TWh by 2035 in both low-emission scenarios (vs. 11 TWh in 2019). All that remains is mainly bioenergy-based cogeneration. However, although bioenergy prices will increase significantly in low-emission scenarios, due to the existing infrastructure of district heating networks, district heating cogeneration

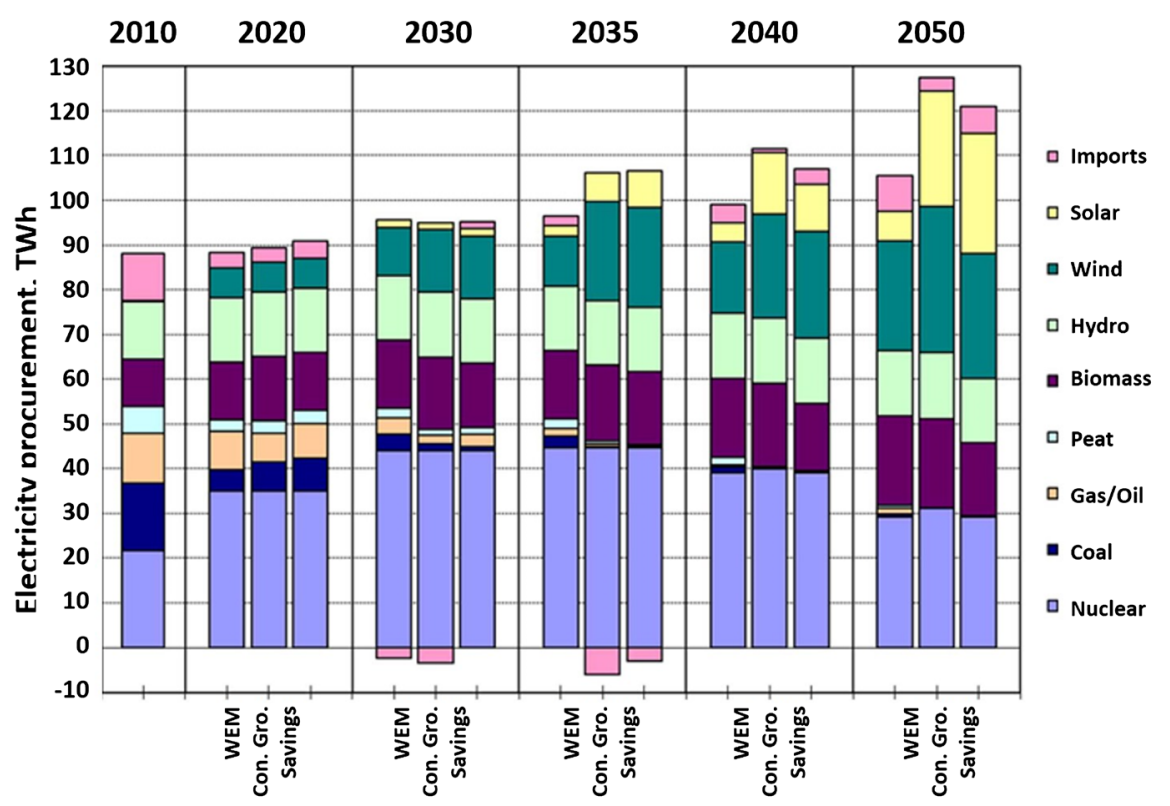

Figure 9. Electricity supply by source under different scenarios [22]. 
will not decrease dramatically. In the separate production of district heating, the use of heat pumps is expanding considerably, which contributes to the energy sector's own electricity consumption. In the Continuous Growth scenarios, industrial CHP rises to a more significant position than communities, as the potential for cogeneration integrated into the forest industry increases, in addition to that, the share of pulp production increases and the heat consumption of paper production decreases.

\subsection{Transportation}

In road transport, a $30 \%$ biofuel distribution obligation has been set for 2030, which will be implemented in both low-emission scenarios. The use of biogas in vehicles can also be significantly expanded, but its importance as a whole remains much smaller than that of other biofuels. The importance of electricity is considerably less than that of biofuels, as the share of combustion engine cars in the car fleet will still be much higher than that of electric cars by 2035 (Figure 10). A significant proportion of fossil diesel remains in particularly heavy traffic, where there are fewer alternative solutions than with passenger cars. This is especially emphasised in the Savings scenario.

\subsection{Student Response to the Survey}

Responses focused on the options somewhat agree or somewhat disagree and the extreme options that agree or disagree were less popular in 2020 (Figure 11). Students were slightly more skeptical than optimistic about achieving the carbon neutrality target. The result indicates the challenge of the target and the associated uncertainty. In 2021, the results were the opposite, the group of students was clearly more positive in their responses. The somewhat agree answer option

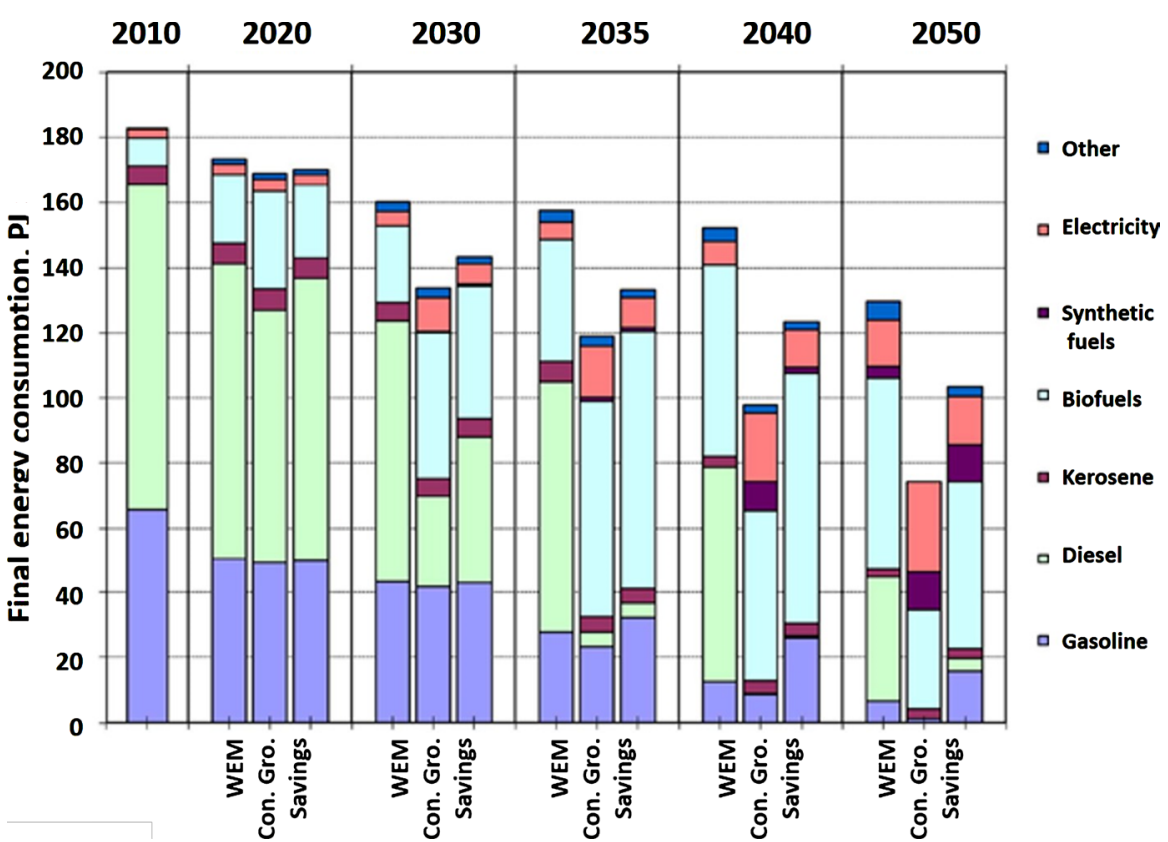

Figure 10. Modelled distribution of transport fuels by scenario [22]. 


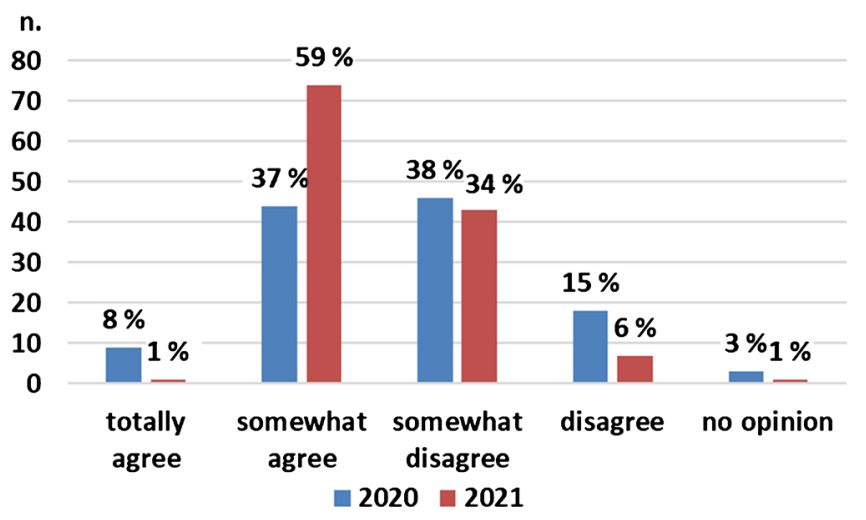

Figure 11. Students' opinions on achieving the carbon neutrality target by 2035 in Finland.

was the most popular. In 2020, gender or form of study were not significant in terms of responses, whereas nationality was relevant $(\mathrm{p}=0.04)$. Foreigners were more optimistic about achieving the target. The field of study or the progress of studies did not matter to full-time students either. In the 2021 group, background variables had no effect on responses. There was a clear difference between the student groups over the years $(\mathrm{p}=0.0005)$.

The students justified the positive attitude towards achieving carbon neutrality by saying that Finland achieved the 2020 goals ahead of schedule and that the government has a strong political will to achieve the 2035 target. In particular, increasing nuclear and wind power were mentioned as an emission-free form of electricity generation. Smart grids and energy storage were seen as a way to increase the share of renewables (wind and solar) in order to balance production and consumption. Energy efficiency and saving was mentioned as a means to curb the growth of energy consumption in all end-use sectors. CCS technology was mentioned as a way to reduce emissions from the use of fossil fuels (natural gas) or from biomass (BECCS). The transport sector was not expected to achieve a carbon-free state on this schedule because of the slow pace of change. Of the other emitting sectors, agricultural and industrial processes were also projected to still be sources of emissions. Therefore, the reinforcement of carbon sinks was seen as important so that the remaining emissions could be offset by forest sinks.

Students who were skeptical about achieving the goal considered the intended timetable, 14 - 15 years, to be too fast. Too fast a transition can also be economically challenging for many energy producers and users. Changes in the energy system are slow, especially in the transport sector, where decisions are based on the choices of the individual car user. Many admitted that several technological solutions are still in the development stage and will not have time to commercialise within this time frame. Such technologies include Power to X (P2X) solutions, Small Nuclear Reactors (SMR), CCS and deep heat geothermal energy, where 2050 is seen as a more realistic time frame for wider deployment. Green hydrogen was seen as one of the P2X products to produce the energy carrier of the future. The implementation of investments was also seen as challenging in 
some cases, e.g., authorisation procedure for nuclear power or regional restrictions on wind power. Surprisingly, the COVID-19 pandemic was seen as a boost to invest in emission-reducing technologies thanks to a comprehensive EU revival package. However, the taxonomy of sustainable financing in the EU defines investments that are classified as sustainable.

Fossil fuels are planned to be significantly replaced by biomass, the availability of which was seen as challenging, and the effort to grow forest sinks was seen as a partly opposite goal. Replacing fossil fuels with renewable energy was seen as a challenge in peak winter electricity and heat consumption situations. There was also a political risk of achieving the goal if decision-makers and the emphasis on different options change. For this reason, regulatory guidance was seen as important because it brings perseverance to corporate decision-making.

Most of the students emphasised the high importance of nuclear energy as a zero-emission form of electricity generation by both 2035 and 2050. No additional potential was seen for hydropower. With regard to nuclear energy, small modular nuclear (SMR) reactors were also often mentioned in the context of heat production in 2050. Wind power and solar power (PV) appeared in the responses of almost everyone as a significantly increasing form of electricity generation. The challenges of increasing their use were recognised in the form of both short- and long-term storage needs to balance supply and demand. Short-term storage would be done using battery technologies and long-term P2X-technologies. As electrification increased, energy savings and demand responses were also emphasised. Admittedly, solar power was seen more as local self-production integrated into the built environment. It was estimated that electricity will also continue to be produced in CHP plants, where biomass will be the main fuel, after the end of coal and peat combustion by 2030 .

The role of bioenergy as a local heating fuel was identified, but its availability and sustainability raised concerns such as the effects of forest biomass use on carbon sinks and biodiversity. Therefore, non-combustible heat sources as heat pumps, waste heat recovery, deep geothermal heat energy and seasonal heat storages will become more widely used. However, biomass plays the most important role as a substitute for the use of peat. Biomass is also needed for the production of biofuels and possible other higher value-added products based on the cascade principle. The role of CCS was seen in two ways, some saw it as a technological option and even an enabler of negative emissions (BECCS) and some saw it more as a promoter of fossil fuel use, and its cost-effectiveness was also questioned. Many responses emphasised that the future zero-emission energy system is the sum of many different actions, with better coordination of production and consumption, where consumers from time to time will also be prosumers.

\section{Discussion}

The reference period until 2035 is short in the energy sector, but significant changes have taken place as renewables have replaced fossil fuels and as electri- 
fication has increased with increasing wind and solar power. In addition to the existing $2586 \mathrm{MW}$ of wind power capacity in 2020, $2142 \mathrm{MW}$ of additional wind power is currently under construction, and these plants are likely to be completed within 2 - 3 years. As a result, the share of wind power in Finland's electricity production will double. In addition, the capacity of wind power projects planned for Finland is approximately 21,300 megawatts (MW). Of these, offshore projects account for about $2800 \mathrm{MW}$ [30]. Together with the power plants now under construction, they would increase wind power production tenfold. Finland has a long west coast and sea area suitable for wind power. Based on this, the target of tripling production by 2035 for wind power growth in low-emission scenarios seems realistic. The development of solar energy in Finland is still in its infancy. At the end of 2019, solar sources generated only 0.2 percent $(0.2 \mathrm{TWh})$ of the country's electricity production with a capacity of 198 MW [31]. Solar energy production is forecasted to grow globally by $16 \%-20 \%$ annually over the next five years [32]. In 2019, more solar energy capacity was built in the EU than any other electricity generation technology, and production increased by more than $100 \%$ year-on-year [32]. In Finland, the growth rate was $64 \%$. The modelled increase in solar power to around 5 TWh by 2035 also seems realistic if the growth rate is maintained.

The modeling of the emission-free energy system at Lappeenranta-Lahti University (LUT) results in much higher electricity production volumes than VTT's TIMES model presented here. LUT's study used the EnergyPLAN advanced energy system analysis computer model [33] to plan a $100 \%$ renewable energy scenario for Finland in 2050 without nuclear. The annual production of electricity is estimated at $166 \mathrm{TWh}$, which is double the current level, and the growth is due to the considerable production of hydrogen and synthetic methane from electricity [7]. Solar electricity would produce 29 TWh (30 GW production capacity) and wind electricity $106 \mathrm{TWh}$ ( $35 \mathrm{GW}$ production capacity) annually by 2050. They are significantly higher than the estimates of the VTT Times model for 2050 with nuclear (cf. Figure 9). In particular, the production of solar electricity requires separate ground-mounted panel fields, because the potential of the roofs of residential buildings in Finland is about $10 \mathrm{GW}$ of electrical power. The annual use of biomass will increase by $50 \%$ from the current level, reaching about 500 PJ, which is quite close to the estimates of VTT's Times model.

In connection with a previous study on Finland, where low-carbon energy system pathways were analysed using the Monte Carlo method, the biggest uncertainties are related to future energy consumption, followed by the amount of wind power and the availability of biomass [34]. The same uncertainties were also observed in the students' responses. Students were unsure of achieving the carbon neutralisation target by 2035. However, student opinion had turned more positive between 2020 and 2021. The debate on the possible tightening of emission reductions in Finland and the EU may have influenced students' opinions. The schedule was considered challenging especially in the transport sec- 
tor, which can also be seen in the scenario pathways. The role of nuclear energy was emphasised in the students' responses as an emission-free form of electricity generation, which is in line with the national energy strategy. Support for nuclear power has increased in Finland on the basis of support measurements made in recent years, and more than half of the respondents are in favour of nuclear power [35]. In that respect, students do not deviate or are even more positive about increasing nuclear power. In the survey, education did not influence the answers, but men were clearly more positive about nuclear power, which may also explain the attitude of predominately male students towards nuclear power.

The increasing use of wind and solar energy requires energy storage solutions that are still under development and causes uncertainty. Bioenergy was also seen as playing an increasing role, especially in heat production. Bioenergy can also have a balancing effect on the renewable electricity system and the potential source for negative emissions as shown in previous studies [36]. Carbon neutrality in energy will be achieved by 2050 through a number of different means, in which the role of energy consumers as future prosumers will also be emphasised. Finland even strives for carbon negativity, which requires solutions that directly utilise carbon dioxide (CCU), either by collecting carbon dioxide from industrial plants or by using direct air capture

\section{Conclusion}

The total final energy consumption in Finland in 2019 was about $300 \mathrm{TWh}$, of which electricity accounted for $29 \%$, heat for about $13 \%$ and direct fuel consumption for $59 \%$. In the future, the share of electricity will increase, while heat and especially direct fuel consumption will decrease. The low-emission scenarios presented here support this development. The development of fossil fuel-based energy production plays a key role in the development of emissions in all low-emission paths, as fossil fuel-based emissions currently account for about $75 \%$ of total greenhouse gas emissions. Achieving significant emission reductions will require significant electrification in all energy end use sectors, as fossil fuels cannot be sustainably replaced by bioenergy on a sufficiently large scale. After 2035, the bioenergy resources will have been fully deployed at levels $\sim 520$ 550 PJ. Bioenergy's share of renewable energy is then $70 \%$, i.e. its relative share has decreased from $82 \%$ in 2019. If BECCS is used, then it is also possible to obtain negative emissions with the help of bioenergy, which facilitates emission reduction efforts in other sectors.

\section{Conflicts of Interest}

The authors declare no conflicts of interest regarding the publication of this paper.

\section{References}

[1] Statistics Finland (2021) Production of Electricity and Heat. 
https://stat.luke.fi/sites/default/files/uusiutuva_energia_2019_ennakko_en.pdf

[2] Ranta, T., Laihanen, M. and Karhunen, A. (2020) Development of the Bioenergy as a Part of Renewable Energy in the Nordic Countries: A Comparative Analysis. Journal of Sustainable Bioenergy Systems, 10, 92-112. https://doi.org/10.4236/jsbs.2020.103008

[3] Fletcher, B., Dettoni, J., Stern, C., Reitenbach, G. and Peltier, R. (2011) Nordic Nations Provide Clean Energy Leadership. Power. https://www.powermag.com/nordic-nations-provide-clean-energy-leadership

[4] Finnish Government (2019) Government Action Plan: Inclusive and Competent Finland-A Socially, Economically and Ecologically Sustainable Society. Publications of the Finnish Government, 29, 64 p. http://urn.fi/URN:ISBN:978-952-287-791-8

[5] Statistics Finland (2021) Greenhouse Gas Inventory Unit. https://www.stat.fi/til/khki/2019/khki_2019_2021-03-19_tie_001_en.html

[6] Hansen, K., Breyer, C. and Lund, H. (2019) Status and Perspectives on 100\% Renewable Energy Systems. Energy, 175, 471-480.

https://doi.org/10.1016/j.energy.2019.03.092

[7] Child, M., Haukkala, T. and Breyer, C. (2017) The Role of Solar Photovoltaics and Energy Storage Solutions in a 100\% Renewable Energy System for Finland in 2050. Sustainability, 9, Article No. 1358. https://doi.org/10.3390/su9081358

[8] Renewable Energy Institute, Agora Energiewende and LUT University (2021) Renewable Pathways to Climate-Neutral Japan. Reaching Zero Emissions by 2050 in the Japanese Energy System. Study on behalf of Renewable Energy Institute and Agora Energiewende.

https://static.agora-energiewende.de/fileadmin/Projekte/2021/2021_03_JP_2050_stu dy/2021_LUT-Agora-REI_Renewable_pathways_Study.pdf

[9] Kristjansdottir, R. and Busch, H. (2019) Towards a Neutral North-The Urban Low Carbon Transitions of Akureyri, Iceland. Sustainability, 11, Article No. 2014. https://doi.org/10.3390/su11072014

[10] Khoodaruth, A., Oree, V., Elahee, M.K. and Clark, W.W. (2018) Mauritius Island Nation: 100\% Renewable Energy System by 2050. In: Clark, W., Ed., Sustainable Cities and Communities Design Handbook: Green Engineering, Architecture, and Technology, Butterworth-Heinemann, 279-306.

[11] Gils, H.C. and Simon, S. (2017) Carbon Neutral Archipelago-100\% Renewable Energy Supply for the Canary Islands. Applied Energy, 188, 342-355.

https://doi.org/10.1016/j.apenergy.2016.12.023

[12] Nanaki, E.A. and Xydis, G.A. (2018) Deployment of Renewable Energy Systems: Barriers, Challenges, and Opportunities. In: Yahyaoui, I., Advances in Renewable Energies and Power Technologies, Elsevier, Amsterdam, 207-229.

[13] Gils, H.C., Simon, S. and Soria, R. (2017) 100\% Renewable Energy Supply for Brazil-The Role of Sector Coupling and Regional Development. Energies, 10, Article No. 1859. https://doi.org/10.3390/en10111859

[14] Bjerregaard, J. (2014) The Transition to a Zero-Carbon Energy Supply. Euroheat and Power (English Edition), 11, 16-18.

[15] Lehmann, H. and Nowakowski, M. (2014) Archetypes of a 100\% Renewable Energies Power Supply. Energy Procedia, 57, 1077-1085.

https://doi.org/10.1016/j.egypro.2014.10.093

[16] Dahal, K. and Niemelä, J. (2016) Initiatives towards Carbon Neutrality in the Hel- 
sinki Metropolitan Area. Climate, 4, Article No. 36.

https://doi.org/10.3390/cli4030036

[17] Kirppu, H., Lahdelma, R. and Salminen, P. (2018) Multicriteria Evaluation of Carbon-Neutral Heat-Only Production Technologies for District Heating. Applied Thermal Engineering, 130, 466-476.

https://doi.org/10.1016/j.applthermaleng.2017.10.161

[18] Hast, A., Syri, S., Welsch, J., Korkmaz, P. and Balyk, O. (2018) Transition to Carbon Neutral Energy Systems-Implications to District Heating in Cities. 2018 15th International Conference on the European Energy Market, Lodz, 27-29 June 2018, 1-5. https://doi.org/10.1109/EEM.2018.8469843

[19] Chen, Y.-K., Jensen, I.G., Kirkerud, J.G. and Bolkesjø, T.F. (2021) Impact of Fossil-Free Decentralized Heating on Northern European Renewable Energy Deployment and the Power System. Energy, 219, Article ID: 119576.

https://doi.org/10.1016/j.energy.2020.119576

[20] Pilpola, S., Arabzadeh, V., Mikkola, J. and Lund, P.D. (2019) Analyzing National and Local Pathways to Carbon-Neutrality from Technology, Emissions, and Resilience Perspectives-Case of Finland. Energies, 12, Article No. 949.

https://doi.org/10.3390/en12050949

[21] Koljonen, T., Aakkula, J., Honkatukia, J., Soimakallio, S., Haakana, M., Hirvelä, H., et al. (2020) Carbon Neutral Finland 2035-Scenarios and Impact Assessment. Vol. 366, VTT Technology, Espoo. (In Finnish). https://www.vttresearch.com/sites/default/files/pdf/technology/2020/T366.pdf

[22] Ministry of Economic Affairs and Employment (2020) Finland's Long-Term Low Greenhouse Gas Emission Development Strategy. https://unfccc.int/sites/default/files/resource/LTS_Finland_Oct2020.pdf

[23] Ministry of Economic Affairs and Employment, Huttunen, R. (ed). (2017) Government Report on the National Energy and Climate Strategy for 2030. 4/2017. (In Finnish). http://urn.fi/URN:ISBN:978-952-327-190-6

[24] Ministry of the Environment (2017) Government Report on Medium-Term Climate Change Plan for 2030-Towards Climate-Smart Day-to-Day Living. 21/2017. (In Finnish) http://urn.fi/URN:ISBN:978-952-11-4748-7

[25] Finnish Government (2019) Government Action Plan: Inclusive and Competent Finland-A Socially, Economically and Ecologically Sustainable Society. 2019: 29. (In Finnish) http://urn.fi/URN:ISBN:978-952-287-791-8

[26] LUKE (2021) Biomass Atlas. https://biomassa-atlas.luke.fi/

[27] Mynttinen, S., Karttunen, K. and Ranta, T. (2014) Non-Industrial Private Forest Owners' (NIPF) Willingness to Supply Forest-Based Energy Wood in the South Savo Region of Finland. Scandinavian Journal of Forest Research, 29, 41-50. https://doi.org/10.1080/02827581.2013.856935

[28] LUKE (2021) MELA Results Service-VMI12 (2014-2018). http://mela2.metla.fi/mela/tupa/index.php

[29] Korpinen, O-J., Lötjönen, T., Lehtonen, E. and Ranta, T. (2015) Geographical Distribution of Techno-Economic Harvest Potential of Straw for Energy Use and Biorefining in Finland. In: Benet Ltd., Book of Proceedings. Bioenergy 2015, Benet Ltd., Jyväskylä, 35-40.

[30] Finnish Wind Power Association (2021) Wind Power Projects in Finland. https://tuulivoimayhdistys.fi/en/wind-power-in-finland

[31] Energy Authority (2020) Aurinkosähkön tuotantokapasiteetti jatkoi kasvuaan 
vuonna 2019-Vuosikasvua 64 prosenttia.

https://energiavirasto.fi/-/aurinkosahkon-tuotantokapasiteetti-jatkoi-kasvuaan-vuo nna-2019-vuosikasvua-64-prosenttia

[32] SolarPower Europe (2020) Global Market Outlook for Solar Power 2020-2024.

https://www.solarpowereurope.org/global-market-outlook-2020-2024/

[33] Lund, H. (2021) Advanced Energy System Analysis Computer Model. EnergyPLAN. http://www.energyplan.eu/

[34] Pilpola, S. and Lund, P.D. (2020) Analyzing the Effects of Uncertainties on the Modelling of Low-Carbon Energy System Pathways. Energy, 201, Article ID: 117652. https://doi.org/10.1016/j.energy.2020.117652

[35] Nurmela, S. (2020) Opinions on Nuclear Power. (In Finnish). https://energia.fi/files/4715/Mielipiteet_ydinvoimasta_2020_-_Raportti.pdf

[36] Johansson, V., Lehtveer, M. and Göransson, L. (2019) Biomass in the Electricity System: A Complement to Variable Renewables or a Source of Negative Emissions? Energy, 168, 532-541. https://doi.org/10.1016/j.energy.2018.11.112 